\title{
FACTORS OF LOCAL E-GOVERNMENT DEVELOPMENT IN POLAND: THE CASE OF THE POZNAŃ AGGLOMERATION*
}

\author{
Robert Perdą \\ Institute of Socio-Economic Geography and Spatial Management, \\ Adam Mickiewicz University in Poznań, Poland \\ Manuscript received: January 22, 2016 \\ Revised version: April 28, 2016
}

Perdą R., 2016. Factors of local e-government development in Poland: The case of the Poznań agglomeration. Quaestiones Geographicae 35(2), Bogucki Wydawnictwo Naukowe, Poznań, pp. 115-129, 2 tables, 1 fig.

AвSTRACT: This paper seeks to analyse factors of e-government development at the local government level in Poland. The analysis proceeded in three stages. In the first, a survey of the literature on the subject was made and a model of factors of e-government development was constructed. In the second, the factors distinguished were operationalised: indicators representing them were constructed. The third stage involved an empirical verification of the model using partial correlation and multiple regression methods; significant factors of e-government development were distinguished at the local government level. The analysis was conducted for a group of 18 communes making up the Poznan agglomeration. It was demonstrated that significant factors of local e-government development in Poland included the level of socio-economic development, inhabitants' access to ICT, their attitudes and skills, the size of administrative units, attitudes of local authorities and leaders, a vision and a strategy of e-government development, human resources in offices, and the financial situation of a commune.

KEY WORDs: local e-government, development factors, public e-services, Poznań agglomeration, Poland

Robert Perdat, Institute of Socio-Economic Geography and Spatial Management, Adam Mickiewicz University in Poznań, Dziegielowa 27, 61-680 Poznań, Poland; e-mail:r.perdal@amu.edu.pl

\section{Introduction}

The appearance and popularisation of information and communications technology (ICT) in human life and activity has revolutionised the sphere of interpersonal communication (van Dijk 2006) and produced profound effects in the operation of the economy, especially the private sector (Castells 2010). Today we witness a 'digital revolution' taking place in the public sector. ICT used in this sector has become one of the significant instruments of its modernisation and internal reform (European governance... 2001, Anttiroiko 2008). This is a response of the public sector to the challenges of contemporary processes, e.g. postmodernity, globalisation, and the development of an information society (Centeno et al. 2005; Anttiroiko 2008). Those are challenges that face the public sector also in Poland (Kaczmarek 2005). An answer is the informatisation of the

* This paper presents the results of a research conducted under the project Model and development factors of electronic administration in local government in Poland, financed from the National Science Centre funds granted on the basis of decision no. DEC-2011/03/N/HS4/00375. 
public sector that has been conducted here for more than a decade now. And since most interactions along the citizen-office line occur at the local administration level (in Poland, the commune and the poviat), it is the operation of e-government at that level that seems to be the most interesting. There also appear many questions about the use of ICT in the public sector and about the effects and consequences of its use for this sector and its customers. For example: how far do Polish local governments follow world trends in the use of ICT in the public sector? What are the effects of and barriers to the development of local e-government? What are the mechanisms and factors of local e-government development in Poland as compared with the experiences of European states?

Hence this paper seeks to analyse factors of local e-government development in Poland. The research procedure had three stages. In the first, a survey of the literature on the subject was made and a model of factors of e-government development was constructed. In the second, the factors distinguished were operationalised by assigning them indicators to represent them. The third stage involved an empirical verification of the model using correlation and regression methods, thus distinguishing significant factors of local e-government development. The analysis was conducted in a group of 18 communes making up the Poznan agglomeration ${ }^{1}$. The time range embraced chiefly the years 2012-2013, because use was made of both quantitative and qualitative data, or a mixed-method research (Ivankova et al. 2006). Quantitative data were of a secondary and primary character. The secondary ones were obtained from Polish official public statistics (the Central Statistical Office), and primary ones from a survey research carried out on a representative sample of 2,654 inhabitants of the Poznań agglomeration. Qualitative data were obtained during interviews conducted with local authorities in the communes under study. In the

\footnotetext{
The choice of the study area was prompted by several considerations, e.g.: it is one of the regions with the highest level of socio-economic development; it is a coherent functional-spatial system with highly developed formal cooperation; it is a relatively small area with spatial units differing in size and character; in Poland, Poznań is one of the leaders in ICT application in the local government operation.
}

research use was made of indicator methods as well as correlation and regression methods: partial correlations and multiple forward stepwise regression (Draper, Smith 1981).

\section{E-government: a tool for a reform of the public sector}

For the first time the notion of electronic government was defined in 1993 in the document From red tape to results: Creating a government that works better and costs less, prepared by Al Gore, vice-president of the USA (Misra 2001). He stated there that "We can design a customer-driven electronic government that operates in ways that, 10 years ago, the most visionary planner could not have imagined. (...) Electronic government will be fairer, more secure, more responsive to the customer, and more efficient than our present paper-based systems." The general vision of e-government involved a modernisation of the public sector by adopting solutions applied in the private one, and was intended to make it more efficient, reduce employment and costs, make administration accessible round the clock, allow on-line payments, etc.

Hence also some authors describing e-government refer to the adoption of an e-business approach in performing public services (Corey, Wilson 2009), thus emphasising the use in the public sector of principles and rules in force in the private one in order to improve its efficiency and the quality of services (van der Heijden 2007). In turn, Anttiroiko (2008) understands e-government as the use of ICT in the public sector to improve the efficiency of its operation by offering citizens and economic entities better access to information and services, and to make interaction and information exchange easier among interested parties while ensuring greater citizen participation in democratic processes. The European Commission proposes a somewhat broader understanding (The role... 2003): e-government is the use of ICT in public administration combined with organisational changes and new skills in order to improve public services, democratic processes and public policies. Hence one can also assume, after Sallmann (2005: 151-152), that e-government is a "'product' of synergy between a reformatory solution of public management 
in public administration and the rapid development of an information society". At this point it is worth observing that there is a feedback between the development of e-government and an information society because public administration, especially the local one, facilitates the development of so-called local information societies through its e-government type of activity (Inkinen, Jauhiainen 2007).

Today e-government is regarded as one of the elements of a reform of the public sector (Anttiroiko 2008). Conceptions for its modernisation with the use of e-government are often identified with new public management (NPM). This approach is justified by Cellary (2002: 94), according to whom "in a new economy administration cannot act in an old way. A person who as a consumer will make ample use via the Internet of products and digital services supplied by the economy, as a citizen will expect and demand a similar form and quality of services from administration". That the efficiency of private administration is higher than that of public administration was already observed by Weber (1976). Hence the fear that the entrenched bureaucracy and its numerous dysfunctions can make the implementation of e-government difficult (Persson, Goldkuhl 2010). Therefore the first thing to do is to reform the public sector in order to eliminate the detrimental effect of bureaucracy (Jain 2004). That is why NPM is often thought to be an internal reform of the public sector intended to make management here equally efficient and effective as in the private one (van Duivenboden, Lips 2005). Those are goals to be achieved via decentralisation, flattening of organisational structures, customer orientation, simplification of procedures, a fast information flow, greater transparency of measures and decisions taken, better-quality management and services, flexible and transparent budgets, higher rationalisation and efficiency, and elimination of dysfunctions (European governance... 2001; van Duivenboden, Lips 2005). In the opinion of Bonina and Cordella (2008), a wide use of ICT when reorganising the public sector is the chief feature of NPM. Still, one should remember that the use of ICT in the public sector was not the chief characteristic of NPM (Margetts 2009). It was only with time, when public entities started to introduce solutions applied in business ever more widely, that
ICT had become an important instrument in the operation of the public sector. The informatisation of the public sector was believed to help rationalise operations, re-engineer the organisation and procedures, and improve the efficiency and quality of public services (Millard 2003; Hill 2004; Cordella 2007).

\section{Systematisation of factors of local e-government development}

Factors of local e-government development were systematised on the basis of the literature on the subject. Regrettably, a thorough analysis of those factors, and especially one based on indepth empirical research, can hardly be found in the world literature. Among the few positions are Grabow et al. (2004), Drüke (2005a) and Paskaleva-Shapira (2009). They present sets of such factors, some of them identical in all those works, but some differing owing to unique local features. For this reason, a start was made by dividing the factors into external and internal ones (Fig. 1). The first group embraced those in the external milieu of the local e-government system (social, economic, political systems, etc.), while the other group included components of this system (politicians, office workers), local governments' material-technical equipment, and relations among them. A synthetic description of the factors distinguished looks as follows.

The first, and one of the most important, external factors of local e-government development is the socio-economic situation of spatial units as determined, among other things, by postmodern processes, globalisation, and the development of an information society. Postmodern processes, which are a consequence of the degradation of traditional industry, manifest themselves, e.g., in a change in socio-economic structures, also in the forms and structures of production, accumulation and regulation (Harvey 1990; Chojnicki 1993). Other symptoms include greater importance of ICT in production and services as well as a flexible organisation involving a new way of management, decentralisation, and quality control. With time all those elements started to spread to the public sector and influence e-government development (Frissen 1998). The effect of globalisation on e-government development 


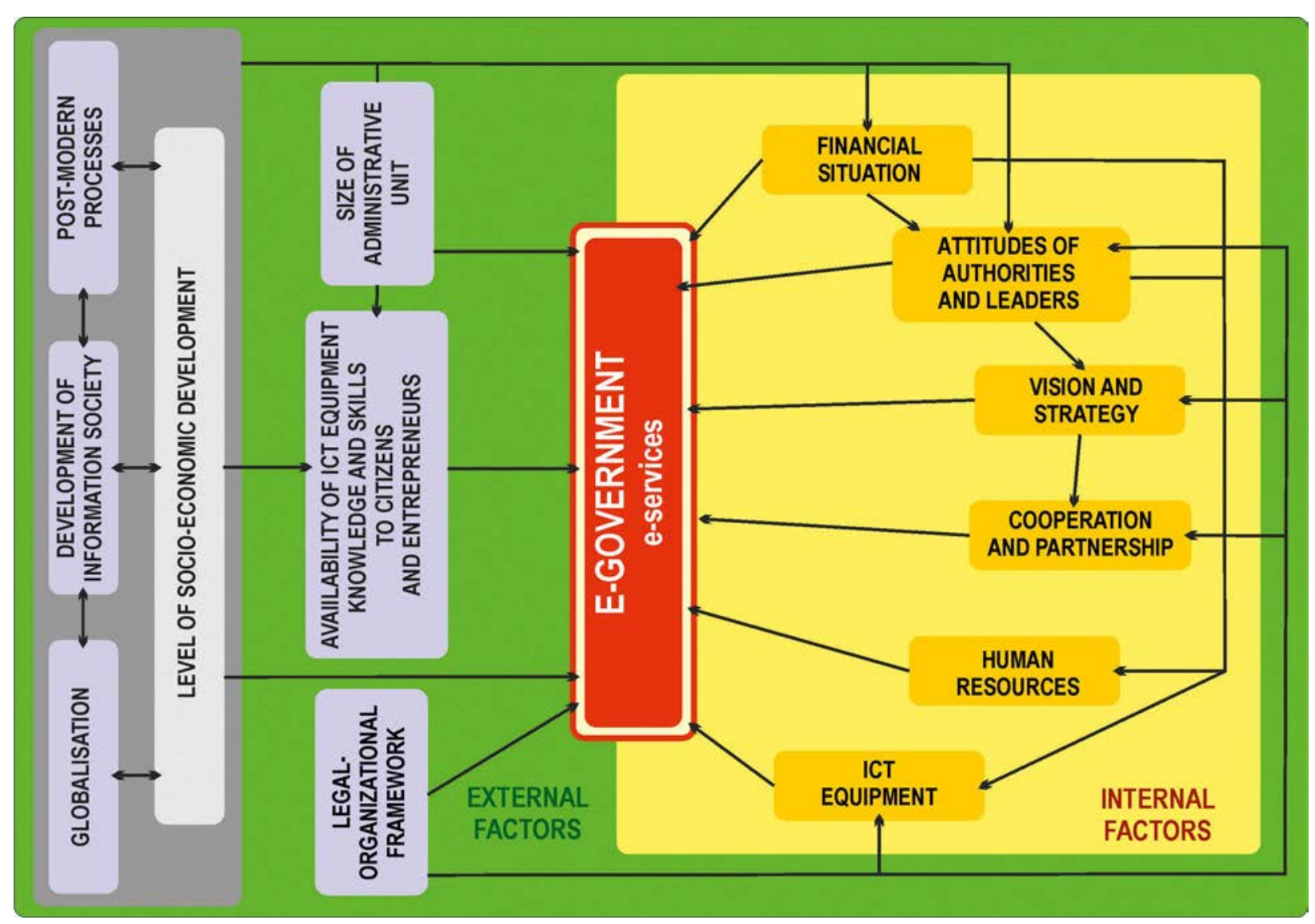

Fig. 1. Model of factors of local e-government development Source: own compilation.

follows especially from the internationalisation of economic cooperation and the inflow of foreign direct investment facilitating an exchange of information and the implementation of innovations, also in organisation and in the use of ICT (Amoretti 2007). Globalisation has reinforced the need for common actions of a global range and exposed two opposites: standardisation and diversification (Stryjakiewicz 2000; Stiglitz 2002). This also holds for e-government. Globalisation enforces a standardisation of data, systems and procedures in order to create services that are supra-national in range and highly inter-operationalised. However, limitations in access to capital (material, financial, human) give rise to such phenomena as digital exclusion. The development and spread of ICT not only affects the economic situation but also initiates significant changes in social systems. Those changes in which information figures so prominently contribute to the development of a new social formation: an information society (Castells 2010). The need to produce, process and utilise information and the wide occurrence and use of various forms of ICT are a significant stimulus of changes in the public sphere, and hence in e-government development as well (Gallego-Álvarez et al. 2010). On the one hand, the above processes stimulate the level of socio-economic development, and on the other, they can be stimulated or blocked by limitations in this field. Taking a broader view, it can be assumed that the level of socio-economic development can influence the level of ICT equipment, and on the other hand, it can determine the level of digital knowledge and skills of inhabitants and entrepreneurs. A higher level of socio-economic development can help in modernising public institutions and improving the financial situation in terms of the available financial resources possible to earmark for e-government development (e.g. better ICT equipment of offices, human resources).

A higher level of socio-economic development also means better ICT accessibility to inhabitants and entrepreneurs, which is a necessary condition for initiating electronic contacts 
with public administration (Musso et al. 2000; Lucke 2007). Besides, often the higher the ICT accessibility to inhabitants and entrepreneurs, the higher their level of digital knowledge and skills. And this is a condition of greater activity on the Web and a higher demand for all kinds of e-services (van Deursen, van Dijk 2009). Van der Meer and van Winden (2003) call those factors a digital flywheel, because they stimulate the public sector to reforms and the digitisation of its activity. Hence the knowledge, skills and attitudes of citizens significantly determine the demand for public e-services, and a limited demand or its absence can result in a limited development of e-government systems. The attitude of citizens towards public e-services follows mostly from their trust in ICT and public administration (Horst et al. 2007; Carter, Weerakkody 2008). This trust is a result of earlier experiences with e-services, usually e-commerce and e-banking, and with contacts with public administration. The level of trust also depends on the level of safety of activities performed on the Internet and the reliability of systems serving them. If customers are sure that public information systems ensure the safety of transactions and the reliability of the information conveyed, they will be more inclined to use public e-services, while empty promises and systems full of errors will discourage them (Bélanger, Carter 2008; Weerakkody et al. 2012). Citizens' knowledge, skills and attitudes are also shaped by their psycho-social and socio-occupational features. The level of education, age and socio-occupational status significantly affect their knowledge of and skills in the use of ICT (Musso et al. 2000). Younger people, those with higher education as well as students and working persons tend to use e-services more frequently than older ones and those with lower education and a lower socio-occupational status (van Dijk et al. 2008). That is why also the more keenly citizens are aware of benefits deriving from public e-services and the higher their ICT skills, the greater their interest in this form of public service provision (van Deursen, van Dijk 2009). In addition, the higher the level of satisfaction of citizens with e-services, the greater their motivation for using next ones and the higher the interest in them of new potential recipients (van der Meer, van Winden 2003). A solution can be an education about the advantages deriving from e-government that can encourage interest in public e-services (Jaeger, Thompson 2003). That is why it is important to ascertain the needs of citizens and entrepreneurs in the field of public e-services. This will allow taking suitable measures designed to satisfy them and improve the image of e-government and its e-services (Centeno et al. 2005; Bertot, Jaeger 2008).

The size of an administrative unit as measured by its population number and area, considered from the point of view of local e-government systems, is connected with the so-called scale effect. Larger communes are more inclined and better able to adopt new, innovative solutions, including e-government (Moon, Norris 2005; Rodríguez-Domínguez et al. 2011). Those communes have more extensive organisational structures allowing them to create departments responsible for e-government implementation, and they also usually have larger funds for putting new solutions into practice (Heller, Farelnik 2013). It is also more probable that they will have residents and entrepreneurs interested in the use of public e-services. Therefore their local governments are under greater pressure of various groups interested in alternative ways of public service provision (Moon 2002). The next issue is the mentality, habits and needs. Inhabitants of small communes trust public authorities more often, but prefer personal contacts with the office, which gives them greater satisfaction and a sense of participating in the life of their commune (Swianiewicz 2001). In large communes relations are more anonymous, hence more formalised contacts are preferred and it is necessary to study the needs of their inhabitants (van Ryzin 2004; Schedler, Summermatter 2007).

The next external factor of local e-government development embraces political conditions and the legal-organisational framework. The acceptance by politicians of reforms of the public sector and their determination to introduce them significantly affects the development of an e-government system, both at the national and the regional and local levels (Carbo, Williams 2004). As follows from experiences gathered so far, today there is no relationship between a political option and e-government development; both left- and right-wing governments support it (GallegoÁlvarez et al. 2010). As experiences of many countries demonstrate, the legal and institutional 
framework can be a factor enhancing e-government development (Heeks 2006; Grabow et al. 2004), but it is emphasised even more often that a disorderly and ambiguous law can be a significant barrier to it (Cellary 2002). Favourable political conditions and a well-ordered legal system make an internal reform of the public sector, especially of its procedures and organisational structures, easier to carry out efficiently. Such measures should first of all involve decentralisation as well as vertical and horizontal integration (Drüke 2005a; Luk 2009). Rigid organisational structures are part of the traditional bureaucratic model of administration and a barrier to e-government development. A re-engineering of the procedures and structures should aim simultaneously (as in business) to maximise efficiency and reduce costs (Millard 2003).

Among the internal factors of local e-government development are attitudes of local authorities, leaders and managerial staff. Their high qualifications and motivation to seek advantages for administration and inhabitants are a key to local e-government development (Heeks 1998; Drüke 2005a, b). Their professionalism implies greater openness to technical and organisational innovations (Moon 2002), which helps them to make proper use of financial, human and technical resources, and primarily to work out a vision and a strategy of e-government development (Luk 2009; Rodríguez-Domínguez et al. 2011). The factors influencing the attitudes of local leaders are their age and education as well as the level of social support and stability of local authorities as indicators of their social and democratic legitimisation making difficult decisions easier to take. In developing countries like Poland, the attitudes of local authorities towards local e-government development often depend on the level of socio-economic development of a local unit and its resultant financial situation. The authorities of units in a good financial condition can be more open to e-government development. This good situation will not make the modernisation and improvement of the operation of a local government to be considered more distant and less significant than the satisfaction of basic needs of a local community. Hence at the local level, especially in smaller communes, a vision and a strategy of e-government development are still thought to be an extravagance and an unnecessary multiplication of strategic documents. However, the choice of goals of e-government development, clearly stated and realistically established in a commune's development strategy, its political priorities and other plans and strategies does not seem to be a difficult task, being also one that can significantly support local government modernisation (Grabow et al. 2004; Gil-Garcia, Pardo 2005; Drüke 2005b).

A necessary condition of local e-government development is ICT equipment (Heeks 1998; Moon 2002), especially the possession of computers, the Internet, including its broad-band version, suitable software and applications, as well as coherent and compatible information systems (Grabow et al. 2004). This is mostly due to the fact that public administration gets informatised first for its own use, and only then for 'external' use, i.e. to serve the needs of citizens and entrepreneurs (Kaczmarek 2005). At an early stage of e-government development (publishing information on the Web) the level of technological advancement is not too high. It grows steeply with the number of public services offered (online forms, full transactions) (Gil-Garcia, Pardo 2005) and the attainment of inter-operationalisation ensuring an exchange of data among public institutions in national and international systems (Fairchild, de Vuyst 2007). However, it should be kept in mind that ill-considered informatisation without internal reorganisation improves ICT equipment, but has no effect on the efficiency of operation and offers no advantages to citizens and entrepreneurs (Cohen, Nijkamp 2004).

The existing ICT infrastructure should be skilfully and effectively used by office workers and persons responsible for the digital service of offices. That is why human resources of communes, and especially their quality as manifested in a high level of competence, qualifications, knowledge and skills (social, technical, organisational) as well as the level of motivation and eagerness for reforms, are among the most important factors of e-government development (Heeks 1998; Gil-Garcia, Pardo 2005). Those characteristics help to increase the efficiency of the public sector and raise the quality of public e-services and contacts with customers (Millard 2003). The motivation of office workers and their attitude towards reforms caused by informatisation are highly significant especially at the initial stage 
of development. Often a barrier is the resistance of office workers themselves, who are afraid that the popularisation of ICT will lead to a reduction in employment and undermine their power and dominant position over the citizen (Heeks 1998). However, the experience of various countries shows those fears to be too pessimistic, because the informatisation of the public sector usually means an increase in employment, though mostly at the initial stage (Bertot, Jaeger 2008).

Apart from the above-mentioned factors, among the most important ones for local e-government development is the financial situation of local governments (Moon 2002; GallegoÁlvarez et al. 2010). As has already been mentioned, budgetary wealth greatly determines the quality and development level of public e-services. Still, it should not have much effect on the content of local Web pages (Baldersheim, Øgård 2008; Gallego-Álvarez et al. 2010). The financial means involved at the early stages of e-government development are not too great. This changes with technological advancement and internal reorganisation (Grabow et al. 2004). Hence the financial situation is more important primarily in the transition to higher stages of e-government development.

The last but one internal factor of local e-government development is cooperation and partnership among various groups of stakeholders in a multi-level system. Their goal is first of all to work out the best possible solutions serving to satisfy local needs and improve local government operation at minimum cost. Those most interested in cooperation for local e-government development are, e.g., all public institutions, entrepreneurs, citizens, non-governmental organisations and associations, as well as higher education and R\&D units (Grabow et al. 2004; Sirkemaa 2007). The cooperation of various public institutions allows them to work out common standards of data and administrative procedures, and to exchange experiences and the use of best practices (Sirkemaa 2007; Ferro, Sorrentino 2010). It often takes the form of partnerships or associations seeking to achieve common tasks and goals. That is why it can take place on organisational ground and in practical activity (common development strategies, infrastructure, digital and personal services, public services; Engel 2004; Cotterill 2009). The cooperation of local governments with citizens, entrepreneurs and associations allows them to learn customers' needs better and to reorganise their activity in order to satisfy them. Local governments cooperating with enterprises can utilise their experiences in organisation and operation, in relations with customers, and in ways of service provision (Kamal et al. 2011). Cooperation with R\&D units can take place on an organisational plane: working out strategies as well as monitoring and evaluating methods, and on a technological one: using available technologies or improving the existing ones (Carbo, Williams 2004; Anttiroiko 2005). Cooperation with the private sector can help the public sector not to fall far behind what the economy has to offer, and it is well known that public administration will not be able to face this challenge by itself. Hence outsourcing and public-private partnerships can greatly contribute to local e-government development.

In a sense, a factor of e-government development is public e-services. There is a very strong feedback between the level of e-government development as expressed by the level of public e-services and those services as a development factor. On the one hand, public e-services are an effect of the operation of e-government, i.e. they are a manifestation of its development. On the other, the introduction of public e-services stimulates organisational changes that boost e-government development. That is why it is often emphasised that public e-services play a great role in local e-government development (van der Meer, van Winden 2003; Aichholzer 2005). The growing interest of citizens and entrepreneurs in public e-services forces public administration to improve their provision. This is mostly achieved by making them accessible through various channels (the telephone, the Internet) and transferring them to higher interaction levels, which is closely connected with technological advancement. This, in turn, stimulates organisational changes and compels office workers to continuously build up their knowledge and skills, which ultimately fosters local e-government development (Aichholzer 2005). It should be kept in mind that public e-services involve not only offering their on-line versions, but also making available all kinds of information and data. The growing demand for a transparent performance of the public sector and citizens' requirements concerning access to 
public information leads to the development of suitable systems of its accumulation, processing and retrieval (Heeks 1998; Kuk 2002). Therefore the higher the quality of public e-services offered, the higher the demand for them, which in turn implies local e-government development.

\section{Empirical verification of the model of factors of local e-government development in Poland: the example of the Poznan agglomeration}

An empirical verification of the model of factors of local e-government development in the communes of the Poznan agglomeration was preceded by the operationalisation of the factors. 39 measures characterising them were created (Table 1). They were built on the basis of the primary and secondary data collected. Excluded from the empirical analysis was the legal-organisational framework. This is due to the fact that this factor affects all communes throughout Poland in a similar way (no differences), and on the basis of the literature on the subject its significance in local e-government development was decided a priori. This level was presented using a synthetic indicator being a total of weighted partial indicators of the interaction of selected public e-services performed and the information content of commune Internet services. This indicator can assume values in a closed interval of $<0$; $100>$ (its broader characterisation can be found in Perdał 2014).

The effect of the model of factors on the level of local e-government development was verified with the help of correlation analysis (Pearson's coefficient of linear correlation, partial correlations) and multiple regression.

An analysis of Pearson's coefficient of correlation showed there to be a high and statistically significant interdependence with the level of local e-government development of two variables representing external factors $\left(X_{11}\right.$ and $\left.X_{13}\right)$ and six representing internal ones $\left(Z_{4^{\prime}} Z_{5^{\prime}} Z_{7}, Z_{8^{\prime}} Z_{16^{\prime}}\right.$ and $Z_{22}$ ). Apart from $Z_{22}$ all variables show a positive correlation. Hence the higher the values of the variables, the higher the level of e-government development, and the higher the dynamics of outlays for administration, the lower the level of e-government development. This situation follows from the fact that outlays for public administration embrace those for commune offices and councils, with the outlays for offices predominant (75-95\%) and involving a rise in salaries. Hence this situation can be interpreted as detrimental to e-government development, i.e. when the outlays for administration grow, but only for wages.

The study of the interdependence between the level of local e-government development and the examined factors, including their indirect effect, was carried out using the partial correlation method $^{2}$. It was conducted in three systems: that of external factors, internal ones, and both systems together.

In the case of external factors, the elimination of the effect of variable $X_{11}$ caused variable $X_{13}$ to lose significance $(r=0.246)$, but there appeared a statistically significant correlation with the level of local e-government development of variables $X_{2}(0.557), X_{3}(0.664), X_{4}(0.520)$ and $X_{5}(0.544)$, which are not correlated with $X_{11}$. This means that there is a strong relationship between the population number and the civic and political activity of inhabitants (0.849), and that they have a combined influence on the level of local e-government development because eliminating one of them weakens the correlation of the other with the level of e-government development and leads to a loss of statistical significance. On the other hand, one can conclude indirectly that candidates for the seat of a councillor are people with higher education, possessing a computer and a cellular phone with Internet access, and that they represent a relatively high level of digital skills, which makes this variable 'weaken' the correlation with the level of e-government development and carry a greater information load. This is corroborated by the fact that when the effect of those variables $\left(X_{2^{\prime}} X_{3^{\prime}} X_{4^{\prime}}\right.$ and $X_{5}$ ) in partial correlations is eliminated, there is an increase in the correlation between the level of e-government development and the number of people running for councillors $\left(\mathrm{r}_{\mathrm{YX} 11} \bullet \mathrm{X}_{2} \mathrm{X}_{3} \mathrm{X}_{4} \mathrm{X}_{5}\right.$ $=0.774$ ). In turn, the elimination of variable $X_{13^{\prime}}$ or the effect of the population number, results in a situation where none of the analysed variables has statistical significance. Hence the population

2 Because of the great number of the variables examined, and hence of possible combinations of partial correlation, this paper presents only a few relationships, those most interesting in the author's opinion. 
Table 1. Factors of local e-government development and their measures

\begin{tabular}{|c|c|c|}
\hline \multicolumn{3}{|r|}{ EXTERNAL FACTORS } \\
\hline factor & & measure \\
\hline $\begin{array}{l}\text { level of socio-economic } \\
\text { development }\end{array}$ & $X_{1}$ & synthetic indicator of socio-economic development $(2012)^{*}$ \\
\hline \multirow{2}{*}{$\begin{array}{l}\text { availability of ICT } \\
\text { infrastructure }\end{array}$} & $X_{2}$ & $\%$ of inhabitants possessing computers with Internet access (2013) \\
\hline & $X_{3}$ & $\%$ of inhabitants possessing cellular phone with Internet access (2013) \\
\hline \multirow{8}{*}{$\begin{array}{l}\text { attitudes, knowledge } \\
\text { and skills of inhabit- } \\
\text { ants and entrepreneurs }\end{array}$} & $X_{4}$ & $\%$ of inhabitants with higher education (2013) \\
\hline & $X_{5}$ & $\%$ of inhabitants with high and very high digital skills (2013) \\
\hline & $X_{6}$ & $\%$ of inhabitants preferring electronic contact with public administration (2013) \\
\hline & $X_{7}$ & $\%$ of inhabitants making use of public e-services (2013) \\
\hline & $X_{8}$ & $\begin{array}{l}\text { \% of people declaring high and very high level of satisfaction with contacts with pub- } \\
\text { lic administration concerning services over Internet at local commune office (2013) }\end{array}$ \\
\hline & $X_{9}$ & $\begin{array}{l}\text { \% of people declaring high and very high level of trust for public administration con- } \\
\text { cerning services over Internet at local office commune (2013) }\end{array}$ \\
\hline & $X_{10}$ & voter turnout at local government elections in 2010 \\
\hline & $X_{11}$ & number of people running for councillors at local government elections in 2010 \\
\hline \multirow{3}{*}{$\begin{array}{l}\text { size of administrative } \\
\text { unit }\end{array}$} & $X_{12}$ & commune area $\left(\right.$ in $\left.\mathrm{km}^{2}\right)(2012)$ \\
\hline & $X_{13}$ & natural logarithm of population number (2012) \\
\hline & $X_{14}$ & population number dynamics $(2006=100 \%)$ \\
\hline \multicolumn{3}{|r|}{ INTERNAL FACTORS } \\
\hline factor & \multicolumn{2}{|r|}{ measure } \\
\hline \multirow{7}{*}{$\begin{array}{l}\text { attitudes of local au- } \\
\text { thorities and leaders }\end{array}$} & $Z_{1}$ & mean age of commune head, mayor, president in 2010 (mean =100) (destimulant) \\
\hline & $Z_{2}$ & $\%$ of votes received by mayor in 1st round of 2010 local government elections \\
\hline & $Z_{3}$ & mean age of councillors in 2010 (destimulant) \\
\hline & $Z_{4}$ & $\%$ of councillors aged up to 40 in 2010 \\
\hline & $Z_{5}$ & $\%$ of councillors with higher education in 2010 \\
\hline & $Z_{6}$ & \% of councillors re-elected in 2010 (as against 2006) \\
\hline & $Z_{7}$ & awareness of the need to develop e-government and openness to innovations (2013) \\
\hline \multirow{2}{*}{$\begin{array}{l}\text { vision and strategy of } \\
\text { e-government devel- } \\
\text { opment }\end{array}$} & $Z_{8}$ & vision of e-government development (2013) \\
\hline & $Z_{9}$ & strategy of e-government development (2013) \\
\hline \multirow[t]{3}{*}{ ICT equipment } & $Z_{10}$ & $\%$ of computers less than 5 years old (2013) \\
\hline & $Z_{11}$ & system of electronic documentation management (2013) \\
\hline & $Z_{12}$ & contact with office through various channels (2013) \\
\hline \multirow[t]{5}{*}{ human resources } & $Z_{13}$ & number of inhabitants per office worker (2013) (destimulant) \\
\hline & $Z_{14}$ & $\%$ of office workers up to 40 years old (2013) \\
\hline & $Z_{15}$ & $\%$ of office workers with higher education (2013) \\
\hline & $Z_{16}$ & digital skills of workers in general in opinion of local authorities (2013) \\
\hline & $Z_{17}$ & courses in informatics for office workers (2006-2013) \\
\hline \multirow[t]{7}{*}{ financial situation } & $Z_{18}$ & mean-annual indicator of own incomes per inhabitant (2006-2012) \\
\hline & $Z_{19}$ & mean-annual indicator of investment outlays per inhabitant (2006-2012) \\
\hline & $Z_{20}$ & mean-annual indicator of balance per inhabitant (2006-2012) \\
\hline & $Z_{21}$ & outlays for administration per inhabitant in 2012 \\
\hline & $Z_{22}$ & dynamics of outlays for administration, 2006-2012 \\
\hline & $Z_{23}$ & mean annual cost of Internet access per inhabitant (2008-2012) \\
\hline & $Z_{24}$ & EU means obtained for e-government development (2006-2013) \\
\hline $\begin{array}{l}\text { cooperation and part- } \\
\text { nership }\end{array}$ & $Z_{25}$ & cooperation of agglomeration communes in e-government development (2006-2013) \\
\hline
\end{tabular}

* The z-score index determined on the basis of 15 uncorrelated variables describing the socio-economic situation.

Source: own compilation. 
number significantly influences the level of local e-government development and determines the effect of the other variables.

In the group of internal factors there are several interesting regularities. On elimination of the effect of variables $Z_{7}$ and $Z_{8^{\prime}}$ most variables for which the correlation was significant and high so far show a considerable decline and lose statistical significance. Hence highly significant factors of local e-government development largely determining a positive effect of other ones are the attitudes of local authorities and leaders as well as the vision and strategy of e-government development worked out.

When examining a combined effect of external and internal factors, it is assumed that the impact of some internal factors on e-government development depends indirectly on that of external ones. It turns out that the elimination of variable $X_{13}$ (population number) brings about a decline in the correlation (and loss of statistical significance) between the level of e-government development on the one hand and the attitudes of local authorities and leaders and human resources on the other $\left(Z_{4}\right.$ from 0.478 to $0.427, Z_{5}$ from 0.495 to $0.230, Z_{7}$ from 0.581 to 0.449 , and $\mathrm{Z}_{16}$ from 0.529 to 0.408 ). This means that those factors largely depend on the size of administrative units and hence they indirectly influence the level of e-government development. There appears another significant dependence when the effect of the level of socio-economic development is eliminated. Although this factor does not show any statistically significant correlation with the level of e-government development, it may affect its internal factors. On its elimination, all coefficients of correlation for internal factors decline, and sometimes they also lose statistical significance $\left(Z_{4}\right.$ and $\left.Z_{5}\right)$. The situation is similar when the effect of the population number factor is eliminated. This is evidence of a strong indirect effect of the level of socio-economic development and the size of administrative units on almost all internal factors of e-government development. In other words, probably the larger a unit and the more advanced its socio-economic development, the more favourable the configuration of the internal factors and their stronger impact on e-government development.

Regression modelling of the effect of the factors distinguished on the level of local e-government development was considered separately for the external and internal factors ${ }^{3}$. This procedure was preceded by a reduction of highly correlated variables. On analysis of Pearson's coefficients of linear correlation (at $p=0.01$ ), 13 variables were eliminated $\left(X_{3^{\prime}}, X_{4^{\prime}} X_{9^{\prime}} X_{13^{\prime}}, Z_{3^{\prime}} Z_{5^{\prime}}, Z_{8^{\prime}} Z_{13^{\prime}}, Z_{15^{\prime}}, Z_{18^{\prime}}\right.$ $Z_{19}, Z_{20}$ and $Z_{22}$ ). In this way a data matrix with 18 communes $\times 10$ variables was obtained for external factors, and one with 18 communes $\times 16$ variables for internal ones.

Regression modelling for independent variables representing external factors yielded a model in the form:

$$
\begin{gathered}
\hat{Y}=58.06+1.32 X_{11}^{*}+0.45 X_{2}^{*}-0.45 X_{7}^{*}+0.86 X_{6}^{*}- \\
-0.27 X_{8}^{*}-0.14 X_{14}-0.09 X_{5}+3.08
\end{gathered}
$$

* - significant at $p=0.05\left(X_{5}\right.$ and $X_{14}$ significant at $p=0.306$ and $p=0.119$, respectively)

$\bar{R}^{2}=0.830[F=12.824 ; d f=7.10 ; p=0.0003]$ residuals from regression - normal distribution (W $\mathrm{S}-\mathrm{W}=0.954$ for $p=0.489$ )

Interestingly, when only those variables that are statistically significant (for $p=0.05$ ) are introduced into the regression model, the corrected coefficient of determination declines to 0.815 and the estimation error grows to 3.21. Hence it can be assumed that variables $X_{5}$ and $X_{14}$, although statistically not significant, reinforce the explanatory power of the model to some extent and can be regarded as indirect factors of e-government development. It is positively correlated with $\mathrm{X}_{11}$ $X_{2}$ and $X_{6}$ : when they increase, so does the level of e-government development. The remaining variables have negative values of coefficient $b$, i.e. their increase should cause a decline in the level of e-government development. This seems to be contradictory, mostly in the case of variables $X_{7^{\prime}}, X_{8^{\prime}} X_{14}$ and $X_{5}$. However, in the communes under study there are more people using other public e-services than those offered by a local government (e.g. e-taxes), and people using local e-services, although at an average level, are highly satisfied with them. In turn, the growing population dynamics of the communes makes it hard for e-government development to 'keep up' with the increase in the population number of a few sub-Poznań communes. More precisely,

This is enforced by the number of communes under study (18), hence the number of variables used in regression modelling cannot be greater than 17 . 
the nearly geometric progression in the population increase in some communes should be accompanied by a similar increase in the level of e-government development - a practically impossible situation. And probably an excessive optimism of the Poznan agglomeration inhabitants in estimating their digital skills as high and very high causes their over-representation and disturbs the model.

For independent variables representing internal factors, the model obtained had the form:

$$
\hat{Y}=57.45+4.79 Z_{7}^{*}+8.88 Z_{16}^{*}-0.38 Z_{14}^{*}+
$$

$+0.25 Z_{6}^{*}-5.94 Z_{23}^{*}+4.92 Z_{25}^{*}-0.01 Z_{21}-2.51 Z_{17}-$

$$
-2.76 Z_{12}+2.09
$$

* - significant at $p=0.05 ;\left(\mathrm{Z}_{12}, \mathrm{Z}_{17}, \mathrm{Z}_{21}\right.$ significant at $p=0.181 ; p=0.180 ; p=0.052$, respectively)

$\bar{R}^{2}=0.921[F=23.025 ; d f=9.8 ; p=0.0000]$ residuals from regression - normal distribution (W $\mathrm{S}-\mathrm{W}=0.979$ for $p=0.946$ )

The inclusion in the model of only statistically significant variables (for $p=0.05$ ) caused the corrected coefficient of determination to drop to 0.891, while the estimation error grew to 2.46 . Therefore, there are additional, although statistically not significant, variables that reinforce the explanatory power of the model. Four variables $\left(Z_{7}, Z_{6}, Z_{16}\right.$, and $\left.Z_{25}\right)$ have positive values of $b$, so their increase means a rise in the level of e-government development. Hence the higher the awareness of the need to develop e-government and openness to innovation among local authorities and leaders, and the higher the digital skills of office workers and the greater the determination to develop inter-commune cooperation, the higher the level of local e-government development. The high proportion of councillors re-elected in local elections can be due to several causes, e.g. their experience and correct choice of the most important problems and tasks to solve, also those resulting from the development of civilisation and a concern for an improvement of the image of a commune as a modern unit, which facilitates taking up more ambitious challenges that involve the informatisation of services and ultimately lead to a better quality of life in the commune. As to the remaining five independent variables, they have negative coefficients, which can be interpreted as a detrimental effect on the level of e-government development. This seemingly contradictory situation can be justified.
First, it was assumed that the growing outlays for the Internet $\left(Z_{23}\right)$ and public administration $\left(Z_{21}\right)$ had a good effect on e-government development (treating them as stimulants). In fact, however, those variables turned out to be destimulants because an increase in outlays for public administration mostly involves an increase in wages rather than an increase in investment outlays. Secondly, the cost of Internet access is not a major barrier to e-government development (at least not in the Poznan agglomeration), this probably being an effect of the situation when communes with a low level of e-government development bear disproportionately high costs of Internet access. For the same reason an increase in the proportion of office workers aged up to $40\left(Z_{14}\right)$, office workers taking part in training courses $\left(Z_{17}\right)$, and the possibility of contact with the office though various channels $\left(Z_{12}\right)$ have a negative sign, which means that communes that have relatively high values of those variables show a lower level of e-government development than would follow from the regression model.

The conducted analysis of the residuals from regression (standardised residuals) shows there to be a good fit of the model to the empirical variables (maximum values oscillating around $\pm 1,2 \sigma$ ). Therefore it can be presumed that factors not considered in the model and unknown ones had a negligible effect on the level of local e-government development in those communes.

\section{Summing up}

The presented synthetic description of factors of local e-government development and their empirical verification with the communes of the Poznan agglomeration as examples show this development to be a multi-aspect process depending on several things. This holds for both, phenomena occurring in the socio-economic and political milieux in which local governments operate as well as those resulting from the internal organisation of the local government. Hence the perception of e-government as a tool for reforming the public sector and intended to bring unusually many benefits must also accommodate the impact of the factors discussed. This means that the establishment of local e-government is a multi-stage process requiring the time and 
determination of many people. What makes it additionally difficult is the fact that e-government conceptions still have not got strong theoretical foundations, and because of the rather modest advances in this field, most of its models and factors are still a sort of generalisations or sets of hypotheses and assumptions, not always verified empirically (Heeks, Bailur 2007). Hence it is hard, especially for decision-makers, to determine correctly what aspects should be stimulated to implement e-government effectively. The identification of significant factors of local e-government development undertaken in this article was supposed to fill in those gaps to some extent.

Nearly all factors (except one) distinguished in the model were shown to affect the level of local e-government development (Table 2). The only one not corroborated in any of the analyses conducted was the ICT equipment of offices. However, this can be due to the fact that the offices examined do not differ much in this respect. Hence, the most important external factors of e-government development for the communes of the Poznan agglomeration are: the level of socio-economic development, inhabitants' access to ICT, their attitudes, knowledge and skills, and the size of administrative units. The internal factors embrace the financial situation, the attitudes and visions of the local authorities and leaders (partly determined by the financial situation), human resources available, and the cooperation established. The legal-organisational framework was excluded from the research procedure because it was taken a priori to be a factor of e-government development. This assumption follows from the situation in which Poland and Polish public institutions found themselves after the state's accession to the European Union. It was then that the process of e-government creation started in practice, because on the one hand it forced Polish legislation to get adjusted to the EU standards and on the other, it gave Polish public institutions access to EU funds earmarked for this purpose. Thereby the analysis conducted confirms the significance and impact of the factors discussed in part three on local e-government development.

Synthetically, those relationships and effects can be characterised as follows. The level of socio-economic development of communes, and in the case under study the size of an administrative unit connected with it, determine and are connected with the level of inhabitants' access to ICT, and their attitudes, knowledge and skills in its possession and use. And this, in turn, tends to depend on their age and education: younger people and those better educated are more ready to rely on ICT to get in touch with public administration and show greater trust in such forms of contact. Those aspects partly motivate local authorities to satisfy the needs of inhabitants who have the technical possibility of using ICT and experience in this matter, e.g. in e-commerce and e-banking, and are also more often inclined to rely on electronic contact with public administration. This motivation translates into creating a suitable vision of e-government development, the details being supplied in strategic documents. This is followed by appropriate measures intended to motivate office workers to improve their education, indicating advantages of and barriers to the use of ICT in public administration, earmarking financial means (as far as possible) for the development of various aspects of e-government (human resources, ICT), all forms of cooperation in solving problems, and looking for good examples in already existing and applied solutions.

It is also worth mentioning that the obtained results come from correlation analysis

Table 2. Factors of local e-government development in the communes of the Poznan agglomeration

\begin{tabular}{|c|c|c|c|c|c|}
\hline \multicolumn{3}{|c|}{ EXTERNAL FACTORS } & \multicolumn{3}{|c|}{ INTERNAL FACTORS } \\
\hline factor & correlation & regression & factor & correlation & regression \\
\hline $\begin{array}{l}\text { level of socio-economic devel- } \\
\text { opment }\end{array}$ & + & & $\begin{array}{l}\text { attitudes of authorities and local } \\
\text { leaders }\end{array}$ & + & + \\
\hline inhabitants' access to ICT & & + & $\begin{array}{l}\text { vision and strategy of e-govern- } \\
\text { ment development }\end{array}$ & + & \\
\hline \multirow{2}{*}{$\begin{array}{l}\text { inhabitants' attitudes, knowl- } \\
\text { edge and skills }\end{array}$} & \multirow[t]{2}{*}{+} & \multirow[t]{2}{*}{+} & ICT equipment & & \\
\hline & & & human resources & + & + \\
\hline \multirow[t]{2}{*}{ size of administrative unit } & \multirow[t]{2}{*}{+} & & financial situation & + & + \\
\hline & & & cooperation and partnership & & + \\
\hline
\end{tabular}

Source: own compilation. 
and regression modelling. This procedure, although applied in spatial-economic research, is also often criticised, especially for the adopted measures of the goodness of fit of regression models. However, the applied procedure with independent variables deriving, sometimes a posteriori, from theoretical premises and from geographical-economic knowledge should minimise the danger of constructing false models and regarding non-significant factors of e-government development as significant. It should be kept in mind, however, that those factors were verified on a rather small sample of communes with highly specific and fairly favourable conditions. This may have biased to some extent the results obtained, but, being a complete case study, it allows the identification in a generalised form of those properties that, when stimulated, can give an impetus to local e-government development in other local governments in Poland, especially those situated in urban agglomerations.

\section{References}

Aichholzer G., 2005. Service take-up and impacts of e-government in Austria. In: Wimmer M.A., Traunmüller R., Grönlund Å., Andersen K.V. (eds), Electronic government. 4th International Conference, EGOV 2005, Proceedings, 3591/2005, Springer-Verlag, Berlin: 93-104.

Amoretti F., 2007. Digital international governance. In: Anttiroiko A-V., Mälkiä M. (eds), Encyclopedia of digital government. Idea Group Reference, Hershey, London: 365-370.

Anttiroiko A.-V., 2005. Urban e-government in Finland. In: Drüke H. (ed.), Local electronic government. A comparative study. Routledge, London-New York: 19-58.

Anttiroiko A.-V., 2008. Introductory chapter. A brief introduction to the field of e-government. In: Anttiroiko A.-V (ed.), Electronic government: Concepts, methodologies, tools, and applications. Information Science Reference, HersheyNew York: xli-lxxv.

Baldersheim H., Øgård M., 2008. Innovation in e-government: Analysis of municipal web pages in the Nordic countries. Information Polity 13(3-4): 125-137.

Bélanger F., Carter L., 2008. Trust and risk in e-government adoption. Journal of Strategic Information Systems 17(2): 165-176.

Bertot J.C., Jaeger P.T., 2008. The e-government paradox: Better customer service doesn't necessarily cost less. Government Information Quarterly 25(2): 149-154.

Bonina C.M., Cordella A., 2008. The new public management, e-government and the notion of 'public value': Lessons from Mexico. AIS Special Interest Group on ICT and Global Development Workshop, Paris, December 13, 2008.

Carbo T., Williams J.G., 2004. Models and metrics for evaluating local electronic government systems and services. The Electronic Journal of e-Government 3(2): 95-104.
Carter L., Weerakkody V., 2008. E-government adoption: A cultural comparison. Information Systems Frontiers 10(4): 473-482.

Castells M., 2010. The rise of the network society. The information age: Economy, society and culture. Vol. 1, Wiley-Blackwell, Oxford.

Cellary W., 2002. Organizacja administracji publicznej na potrzeby obywateli (Organisation of public administration for the needs of citizens). In: Cellary W. (ed.), Polska w drodze do globalnego społeczeństwa informacyjnego. Raport o rozwoju społecznym. UNDP Program Narodów Zjednoczonych ds. Rozwoju, Warszawa: 94-97.

Centeno C., van Bavel R., Burgelman J.C., 2005. A prospective view of e-government in the European Union. The Electronic Journal of e-Government 3(2): 59-66.

Chojnicki Z., 1993. Postmodernistyczne zmiany globalnego porządku społeczno-gospodarczego (Postmodern changes in the global socio-economic order). In: Kukliński A. (ed.), Polonia, quo vadis? Studia Regionalne i Lokalne 12(45): 167-204.

Cohen G., Nijkamp P., 2004. City, ICT and policy. Investigaciones Regionales 4(1): 29-51.

Cordella A., 2007. E-government: Towards the e-bureaucratic form? Journal of Information Technology 22(3): 265-274.

Corey K.E., Wilson M.I., 2009. E-business and e-commerce. In: Kitchin R., Thrift N. (eds), International Encyclopedia of Human Geography 3: 285-290.

Cotterill S., 2009. Local e-government partnerships. In: Reddick C.G. (ed.), Handbook of research on strategies for local e-government adoption and implementation: Comparative studies. Information Science Reference, Hershey-New York: 105-121.

van Deursen A., van Dijk J., 2009. Improving digital skills for the use of online public information and services. Government Information Quarterly 26(2): 333-340.

van Dijk J., 2006. The network society. Social aspects of new media. SAGE, London.

van Dijk J., Peters O., Ebbers W., 2008. Explaining the acceptance and use of government Internet services: A multivariate analysis of 2006 survey data in the Netherlands. Government Information Quarterly 25(3): 379-399.

Draper N., Smith H., 1981. Applied regression analysis. John Wiley \& Sons, New York.

Drüke H., 2005a. Introduction. In: Drüke H. (ed.), Local electronic government. A comparative study. Routledge, London-New York: 1-18.

Drüke H., 2005b. Concluding remarks on national specifics and transfer and adoption of good practice. In: Drüke H. (ed.), Local electronic government. A comparative study. Routledge, London-New York: 269-292.

van Duivenboden H., Lips M., 2005. Responsive e-government services: Towards 'new' public management. In: Bakkers V., Homburg V. (eds), The Information Ecology of e-Government. E-Government as Institutional and Technological Innovation in Public Administration. IOS Press: 141-154.

Engel A., 2004. The economic evaluation of e-government: The right strategic decision? German Journal of Urban Studies (Deutsche Zeitschrift für Kommunalwissenschaften DfK), 2/2004, Deutsches Institut für Urbanistik, Berlin (http://www.difu.de).

European Governance and Cyberdemocracy, 2001. European Commision, Brussels. 
Fairchild A., Vuyst de B., 2007. Governmental collaboration and infrastructural standards in Belgium. The Electronic Journal of e-Government 5(2): 145-152.

Ferro E., Sorrentino M., 2010. Can intermunicipal collaboration help the diffusion of e-government in peripheral areas? Evidence from Italy. Government Information Quarterly 27(1): 17-25.

Frissen P.H.A., 1998. Public administration in cyberspace. In: Snellen I.Th.M., van de Donk W.B.H.J. (eds), Public administration in an information age. A handbook. IOS Press, Amsterdam: 33-46.

From red tape to results: Creating a government that works better and costs less, 1993, NPR 93-a Report of the National Performance Review (http:/ / www.nsf.gov/pubs/stis1993/ npr93a/npr93a.txt).

Gallego-Álvarez I., Rodríguez-Domínguez L., GarcíaSánchez I.M., 2010. Are determining factors of municipal e-government common to a worldwide municipal view? An intra-country comparison. Government Information Quarterly 27(4): 423-430.

Gil-Garcia J.R., Pardo T.A., 2005. E-government success factors: Mapping practical tools to theoretical foundations. Government Information Quarterly 22(2): 187-216.

Grabow B., Drüke H., Siegfried C., 2004. Factors for success for local community e-government. German Journal of Urban Studies (Deutsche Zeitschrift für Kommunalwissenschaften DfK), 2/2004, Deutsches Institut für Urbanistik, Berlin (http://www.difu.de).

Harvey D., 1990. The condition of postmodernity. An enquiry into the origins of cultural changes. Blackwell, CambridgeOxford.

Heeks R., 1998. Information systems for public sector management. Working Paper Series 5, Public Sector Management Information Systems, Institute for Development Policy and Management, Manchester.

Heeks R., 2006. Implementing and managing e-government. SAGE, London.

Heeks R., Bailur S., 2007. Analyzing e-government research Perspectives, philosophies, theories, methods, and practice. Government Information Quarterly 24(2): 243-265.

van der Heijden J., 2007. How business changes government in the information age. In: Anttiroiko A.-V., Mälkiä M. (eds), Encyclopedia of Digital Government. Idea Group Reference, Hershey, London: 928-932.

Heller J., Farelnik E., 2013. Finanse i samodzielność ekonomiczna a ustrój samorządów terytorialnych w Polsce (Finances and economic independence versus the local government system in Poland). Studia Regionalne $i$ Lokalne 2(52): 81-94.

Hill H., 2004. Transformation of the administration by e-government. German Journal of Urban Studies (Deutsche Zeitschrift für Kommunalwissenschaften DfK), 2, Deutsches Institut für Urbanistik, Berlin (http://www. difu.de).

Horst M., Kuttschreuter M., Gutteling J.M., 2007. Perceived usefulness, personal experiences, risk perception and trust as determinants of adoption of e-government services in The Netherlands. Computers in Human Behavior 23(4): 1838-1852.

Inkinen T., Jauhiainen J.S., 2007. Public authorities and the local information society. In: Anttiroiko A.-V., Mälkiä M. (eds), Encyclopedia of digital government. Idea Group Publishing, Information Science Publishing, Hershey, London: 1370-1376.
Ivankova N.V., Creswell J.W., Stick S.L., 2006. Using mixed-methods sequential explanatory design: From theory to practice. Field Methods 18(1): 3-20.

Jaeger P.T., Thompson K.M., 2003. E-government around the world: Lessons, challenges, and future directions. Government Information Quarterly 20(3): 389-394.

Jain A., 2004. Using the lens of Max Weber's theory of bureaucracy to examine e-government research. Proceedings of the 37th Hawaii International Conference on System Sciences (www. hicss. hawaii. edu/diglib.htm).

Kaczmarek T., 2005. Struktury terytorialno-administracyjne $i$ ich reformy $w$ krajach europejskich (Territorial-administrative structures and their reform in European countries). Wydawnictwo Naukowe UAM, Poznań.

Kamal M., Weerakkody V., Irani Z., 2011. Analyzing the role of stakeholders in the adoption of technology integration solutions in UK local government: An exploratory study. Government Information Quarterly 28(2): 200-210.

Kuk G., 2002. The digital divide and the quality of electronic service delivery in local government in the United Kingdom. Government Information Quarterly 20(4): 353-363.

Lucke J., 2007. Portals for the public sector. In: Anttiroiko A.-V., Mälkiä M. (eds), Encyclopedia of Digital Government. Idea Group Reference, Hershey, London: 1328-1333.

Luk S.C.Y., 2009. The impact of leadership and stakeholders on the success/failure of e-government service: Using the case study of e-stamping service in Hong Kong. Government Information Quarterly 26(4): 594-604.

Margetts H., 2009. Public management change and e-government: The emergence of digital-era governance. In: Chadwick A., Howard P.N. (eds), Routledge Handbook of Internet Politics. Routledge, London: 114-127.

van der Meer A., van Winden W., 2003. E-governance in cities: A comparison of urban information and communication technology policies. Regional Sudies 37(4): 407-419.

Millard J., 2003. ePublic services in Europe: Past, present and future. Research findings and new challenges. Danish Technological Institute, Aarhus.

Misra D.C., 2001. Select aspects of conceptual foundations of e-government: Clearing the fog for a better vision. Foundations of E-government, GIFT Publishing: 21-33.

Moon M.J., 2002. The evolution of e-government among municipalities: Rhetoric or reality? Public Administration Review 62(4): 424-433.

Moon M.J., Norris D.F., 2005. Does managerial orientation matter? The adoption of reinventing government and e-government at the municipal level. Information Systems Journal 15(1): 43-60.

Musso J., Weare C., Hale M., 2000. Designing Web technologies for local governance reform: Good management of good democracy? Political Communication 17: 1-17.

Paskaleva-Shapira K., 2009. Assessing local readiness for city e-governance in Europe. In: Reddick C.G. (ed.), Handbook of research on strategies for local e-government adoption and implementation: Comparative studies. Information Science Reference, Hershey-New York: 62-82.

Perdał R., 2014. Czynniki rozwoju elektronicznej administracji $w$ samorzadzie lokalnym $w$ Polsce (Factors of e-government development in the local government in Poland). Bogucki Wydawnictwo Naukowe, Poznań.

Persson A., Goldkuhl G., 2010. Government value paradigms - bureaucracy, new public management, and e-government. Communications of the Association for Information Systems 27(4): 45-62. 
Rodríguez-Domínguez L., García-Sánchez I.M., Gallego-Álvarez I., 2011. Determining factors of e-government development: A worldwide national approach. International Public Management Journal 14(2): 218-248.

van Ryzin G.G. 2004. Expectations, performance, and citizen satisfaction with urban services. Journal of Policy Analysis and Management 23(3): 433-448.

Sallmann R., 2005. Ogólnokrajowy rozwój e-government. Austriackie formy rozwiązań (National development of e-government. Austrian solutions). In: Proniewicz J., Szczepańska K. (eds), Efektywna polityka i administracja. Strategie i instrumenty zarzadzania miastami. Związek Miast Polskich, Österreichicher Städtebund, KDZ - Zentrum für Verwaltungsforschung, Poznań: 151-177.

Schedler K., Summermatter L., 2007. Customer orientation in electronic government: Motives and effects. Government Information Quarterly 24(2): 291-311.

Sirkemaa S., 2007. The role of partnerships in development of e-services - highlighting public sector organizations. International Journal of Public Information Systems 3(3): 201-212.

Stiglitz J.E., 2002. Globalization and its discontents. W.W. Norton \& Company, New York.

Stryjakiewicz T., 2000. Implications of globalisation for regions and localities in an economic transition: The case of Poland. In: Parysek J.J., Stryjakiewicz T. (eds), Polish economy in transition. Spatial perspectives. Bogucki Wydawnictwo Naukowe, Poznań: 7-28.

Swianiewicz P., 2001. Życzliwa obojętność. Władze lokalne i reforma samorzadowa w oczach opinii publicznej w krajach Europy Środkowej (Friendly indifference. Local authorities and the local-government reform in the public opinion of Central European countries). EUROREG, Local Government and Public Service Reform Initiative of the Open Society Institute, Warszawa.

The Role of eGovernment for Europe's Future, 2003. Communication from the Commission to the Council, the European Parliament, the European Economic and Social Committee and the Committee of the Regions, 26 Sept. 2003, COM 2003 (567) final, Brussels.

Weber M., 1976. Wirtschaft und Gesellschaft: Grundriss der verstehenden Soziologie. J.C.B. Mohr (Paul Siebeck), Tübingen.

Weerakkody V., El-Haddadeh R., Sabol T., Ghoneim A., Dzupka P., 2012. E-government implementation strategies in developed and transition economies: A comparative study. International Journal of Information Management 32(1): 66-74. 